\title{
Bilateral Brown's syndrome in a mother and her son: case report
}

\author{
Síndrome de Brown bilateral em mãe e filho: relato de caso
}

\author{
Rosália Maria Simões Antunes-Foschini ${ }^{1}$ \\ Harley Edison Amaral Bicas ${ }^{2}$
}

From Department of Ophthalmology, School of Medicine of Ribeirão Preto, Universidade de São Paulo - USP - Ribeirão Preto (SP) - Brazil.

${ }^{1}$ Department of Ophthalmology, School of Medicine of Ribeirão Preto, Universidade de São Paulo - USP - Ribeirão Preto (SP) - Brazil.

${ }^{2}$ Department of Ophthalmology, School of Medicine of Ribeirão Preto - USP - Ribeirão Preto (SP) - Brazil.

Correspondence address to: Rosália M. S. Antunes-Foschini. Av. Caramuru, 1280 - Apto. 85 - Ribeirão Preto (SP) Zip Code 14030-000

E-mail address: rantunes@convex.com.br

Recebido para publicação em 01.10.2006

Última versão recebida em 24.02.2008

Aprovação em 06.05.2008

Nota Editorial: Depois de concluída a análise do artigo sob sigilo editorial e com a anuência do Dr. Marcelo Francisco Gaal Vadas sobre a divulgação de seu nome como revisor, agradecemos sua participação neste processo.

\section{ABSTRACT}

This case report describes clinical data from mother and son with bilateral Brown's syndrome and highlights possible genetically determined predispositions.

Keywords: Ocular motility disorders/genetics; Ocular motility disorders/pathology; Strabismus/ congenital; Syndrome; Tendons/physiopathology; Oculomotor muscles/physiopathology; Case reports [Publication type]

\section{INTRODUCTION}

Brown's syndrome (or superior oblique tendon sheath syndrome) was first described by Brown in $1950^{(1)}$. This motility defect consists of the inability to raise the adducted eye above the midhorizontal plane, with a positive forced duction test in supra-adduction. Less elevation restriction can be found in the midline and a smaller elevation deficiency is detectable in abduction. Exodeviation usually increases as the eyes move upwards above the midline.

In 1973 Brown redefined this syndrome ${ }^{(2)}$ and divided it into two subtypes, i.e., true and simulated sheath syndrome. The true syndrome is congenital, permanent and invariably associated with a positive traction test of the involved adducted eye in the field of elevation. The true syndrome is the most common form ${ }^{(2-3)}$. Many reports have tried to elucidate the true form and its etiologies. A taut superior oblique tendon ${ }^{(1-3)}$ is a possible cause. Katz et al. ${ }^{(4)}$ reported Brown's syndrome in monozygotic twin girls. Association with autosomal dominant pathology ${ }^{(5)}$ and genetic inheritance have also been reported ${ }^{(6-7)}$.

We describe here the eye examination of two cases of bilateral Brown's syndrome occurring in mother and son.

\section{CASE 1}

A seven-year-old boy was referred to us because his mother noticed that he could not elevate his eyes, with an exodeviation occurring when he tried to elevate them, since the age of 8 months. The medical history of the boy and his family was unremarkable and the child had no complaints. Eye examination revealed $1.0(\log \mathrm{MAR}=0)$ visual acuity in each eye, cycloplegic refraction was +1.00 spheric diopter in each eye, both pupils were reactive to light, and slit lamp examination and indirect fundoscopy were within normal limits. Motility examination (Figure 1) showed an abnormal head position with a mild chin elevation. In the cover test, he showed ortophoria in an abnormal head position and a small exophoria in the primay position. In dextroversion, he had right hypertropia and in levoversion he had left hy- 
pertropia associated with the inability to elevate both eyes in adduction. He showed a marked $\mathrm{V}$ pattern when he tried to look upwards, with the appearance of significant exotropia. In infraversion, he was orthophoric. The forced duction test in the field of action of each inferior oblique muscle showed a clear inability of both eyes to elevate. In abduction, there was a small restriction of elevation of the right eye. The Titmus test showed normal stereopsis (40"). The boy was followed up for two years, with no new findings being observed.

\section{CASE 2}

The mother of the boy (case 1) had the same motility defect (Figure 2), observed by her husband some years ago. She was
32 years old and reported no previous inflammatory diseases. Her visual acuity was $1.0(\log \mathrm{MAR}=0)$ in each eye and slit lamp examination and fundoscopy were equally normal. When submitted to the cover test, she showed orthophoria in the primary position and in infraversion. In supraversion, there was important exotropia, as observed in her son, showing a V pattern. She was also unable to elevate both eyes in adduction. In dextro- and levoversion she showed right and left hypertropia, respectively. The forced duction test could not be done. The Titmus test revealed stereopsis of 40".

The boy appears to have a true Brown's syndrome. Although the mother has the same clinical findings, she was not examined previously. A forced duction test was not performed on her, but it appears that she has also a Brown's syndrome.
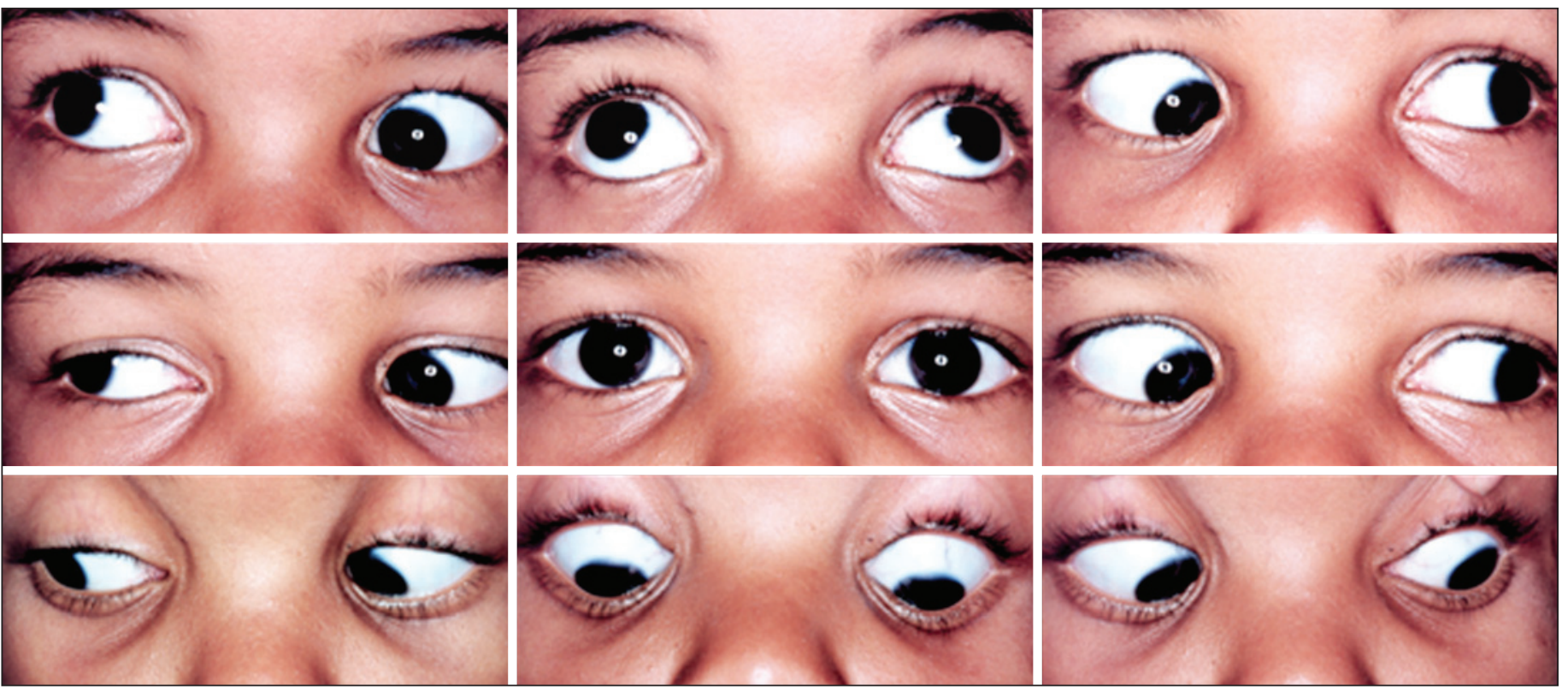

Figure 1 - The nine positions of gaze, boy
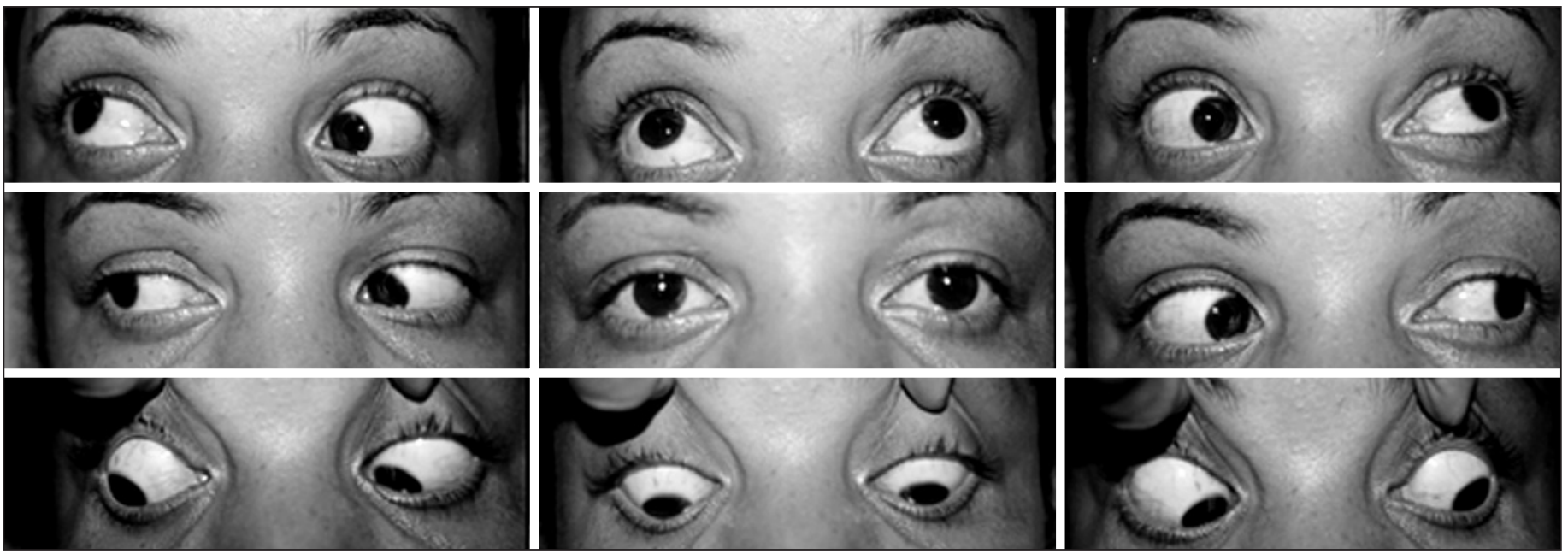

Figure 2 - The nine positions of gaze, mother 


\section{DISCUSSION}

Little is known about the pathogenesis of true Brown's syndrome ${ }^{(2,6)}$. Although the superior oblique tendon is usually found to be abnormally taut ${ }^{(1-2,8)}$, the cause of this anatomic dysfunction is still unknown, but some previously published case reports $^{(4-5,7,9)}$ have suggested a genetically determined predisposition in this syndrome, consistent with recessive inheritance at the DURS1 locus and dominant inheritance with reduced penetrance at the DURS1, DURS2, and FEOM1 loci ${ }^{(7)}$. The almost perfectly symmetrical bilateral Brown's syndrome found in the here reported mother and child supports this hypothesis.

\section{RESUMO}

Este relato de caso descreve achados clínicos de mãe e filho com síndrome de Brown bilateral e discute a possibilidade de predisposição genética.

Descritores: Transtornos da motilidade ocular/genética; Transtornos da motilidade ocular/patologia; Estrabismo/congênito;
Síndrome; Tendões/fisiopatologia; Músculos oculomotores/ fisiopatologia; Relatos de casos [Tipo de publicação]

\section{REFERENCES}

1. Brown HW. Strabismus ophthalmic symposium 1. St. Louis: Mosby Year Book; 1950. p.205.

2. Brown HW. True and simulated superior oblique tendon sheath syndromes. Doc Ophthalmol. 1973;34(1):123-36.

3. Parks MM, Brown M. Superior oblique tendon sheath syndrome of Brown. Am J Ophthalmol. 1975;79(1):82-6.

4. Katz NN, Whitmore PV, Beauchamp GR. Brown's syndrome in twins. J Pediatr Ophthalmol Strabismus. 1981;18(1):32-4.

5. Lobefalo LT, Mancini AT, Petitti MT, Verrotti AE, Della Loggia GE, Di Muzio $\mathrm{AE}$, et al. A family with autosomal dominant distal arthrogryposis multiplex congenita and Brown syndrome. Ophthalmic Genet. 1999;20(4):233-41. Comment in: Ophthalmic Genet. 2001;22(2):125-30.

6. Paul TO, Hardage LK. The heritability of strabismus. Ophthalmic Genet. 1994;15(1):1-18.

7. Iannaccone A, McIntosh N, Ciccarelli ML, Baldi A, Mutolo PA, Tedesco SA, Engle EC. Familial unilateral Brown syndrome. Ophthalmic Genet. 2002; 23(3):175-84.

8. von Noorden GK, Olivier P. Superior oblique tenectomy in Brown's syndrome. Ophthalmology. 1982;89(4):303-9.

9. Kim SH, Ben-Zion I, Neely DE. Bilateral Brown syndrome in monozygotic twins. J AAPOS. 2008;12(2):193-4. 